\title{
Duplex real-time reverse transcriptase PCR to determine cytokine mRNA expression in a hamster model of New World cutaneous leishmaniasis
}

\author{
Claudia M Espitia1,2, Weiguo Zhao 1,2, Omar Saldarriaga1,2, Yaneth Osorio 1,2, Lisa M Harrison³, Michael Cappello3, \\ Bruno L Travi ${ }^{1,2}$ and Peter C Melby*1,2,4
}

\begin{abstract}
Background: The Syrian hamster, Mesocricetus auratus, has distinct immunological features and is uniquely susceptible to intracellular pathogens. Studies in hamsters are limited by the relative unavailability of tools to conduct immunological studies. To address this limitation we developed duplex real-time reverse transcriptase (RT) PCR assays for the relative quantification of the mRNAs of hamster cytokines, chemokines, and related immune response molecules.

Results: Real-time RT-PCR primers and probes were synthesized for analysis of interleukin (IL)-4, IFN- $\gamma$, TNF-a, IL-10, IL12p40, TGF- $\beta$, IL-13, IL-21, chemokine ligand (CCL) 22, CCL17, Chemokine (C-C motif) receptor 4 and FoxP3 expression. Standard curves and validation experiments were performed for each real-time RT-PCR assay, allowing us to use the comparative Ct (2- $-\Delta \Delta \mathrm{Ct})$ method to calculate changes in gene expression. Application of the real-time RT PCR assays to a biological model was demonstrated by comparing mRNA expression in skin and lymph node tissues between uninfected and Leishmania panamensis infected hamsters.

Conclusions: The duplex real-time RT PCR assays provide a powerful approach for the quantification of cytokine transcription in hamsters, and their application to a model of cutaneous leishmaniasis suggests that a balanced type 1 and type 2 cytokine response contributes to the chronic, nonprogressive course of disease. These new molecular tools will further facilitate investigation into the mechanisms of disease in the hamster, not only for models of leishmaniasis, but also for other viral, bacterial, fungal, and parasitic infections.
\end{abstract}

\section{Background}

The Syrian golden hamster (Mesocricetus auratus) is highly susceptible to a number of human pathogens. The hamster has been described as a relevant experimental model that more representative of human disease than either the mouse or rat models for a number of human pathogens, including Leishmania (Viannia) spp. [1-4], L. donovani [5,6], Trypanosoma cruzi [7], Entamoeba histolytica [8], Leptospira and Treponema [9,10], hantavirus [11], Eastern equine encephalitis virus [12], Yellow Fever virus [13,14], West Nile virus [15], Nipah virus [16], hookworm [17], and various fungi and mycobacteria. Unfortunately, the use of the hamster in research has

\footnotetext{
* Correspondence: melby@uthscsa.edu
}

${ }^{1}$ Research Service, Department of Veterans Affairs Medical Center, South Texas Veterans Health Care System, 7400 Merton Minter, San Antonio, Texas, USA Full list of author information is available at the end of the article been hindered by the lack of commercially available immunological and molecular reagents to investigate mechanisms of disease.

The cloning and sequence analysis of portions of Syrian hamster interleukin 2 (IL-2), IL-4, gamma interferon (IFN- $\gamma$ ), tumor necrosis factor alpha (TNF- $\alpha$ ), IL-10, IL$12 \mathrm{p} 40$, and transforming growth factor beta (TGF- $\beta$ ) cDNA were reported previously [6], and these sequences have been used by a number of investigators to measure cytokine expression by northern blotting and conventional semi-quantitative RT-PCR $[5,6,18,19]$. More recently real-time quantitative reverse transcription-PCR assays for the quantification of cytokine mRNA expression using two-step SYBR green I RT-PCR protocols were used [20-22]. 
Studies in animal models of parasitic infections have shown that $\mathrm{T}$ lymphocytes and cytokines play a crucial role in the outcome of infection, both in terms of protective immunity and immunopathology. Of particular interest is the evidence that parasitic infections can trigger polarized $\mathrm{CD}^{+} \mathrm{T}$ cell subset responses, and that cytokines produced by different Th1 or Th2 cells in the host can have opposing effects, resulting in either control of infection or promotion of disease [23]. There is enormous variety in the expression patterns of cytokine genes, i.e., they can be either constitutively expressed or can be activated or repressed when a cell is exposed to a particular signal [24]. Most of these responses appear to be controlled at the level of transcription and mRNA stability $[22,25]$ so quantification by real-time RT PCR is widely used to investigate the immune response to various stimuli.

To better understand the hamster immune response to important pathogens, we determined the nucleotide sequence of additional hamster cytokines and chemokines (IL-13, IL-21, CCL17, CCL22), one chemokine receptor (CCR4), and one transcriptional factor (Foxp3). These cDNAs were chosen for study because of their role in a type 2 or regulatory $T$ cell response, both of which have potential importance in the immunopathogenesis of leishmaniasis. This technical report describes the standardization of One Step (Taqman) Real Time PCR for the detection of these hamster mRNAs, and their application was validated in a model of localized cutaneous leishmaniasis.

\section{Results and Discussion}

The Syrian hamster, because of its distinct immunological features and susceptibility to intracellular pathogens provides a unique opportunity for study of models relevant to human disease. However, studies in hamsters are limited by the relative unavailability of tools to conduct immunological studies. Previously, we identified sequences for several hamster cytokine cDNAs and used these to assess the immunological responses to infection using Northern blotting and conventional RT-PCR. We have now extended these studies by isolating and cloning a number of additional hamster cDNAs and developing and standardizing duplex real-time RT PCR assays for measurement of gene expression of 12 different mRNAs, which included cytokines, chemokines, a chemokine receptor and a transcription factor. While the measurement of protein levels has the most relevance to understanding immunopathogenesis and immunity, most cytokines/immune response genes are transcriptionally regulated, enabling the use of quantitative real time PCR to detect and quantify their expression. We were particularly interested in measuring the expression of these
mRNAs because of their potential role in the immunopathogenesis of cutaneous leishmaniasis.

The newly isolated and cloned cDNAs included small portions of hamster IL-13, IL-21 and FoxP3, and the complete open reading frame (ORF) of the hamster CCL17, CCL22 and CCR4. All the cDNA sequences (excluding primers) were analyzed using Basic Local Alignment Search Toll (BLAST) [26] from the National Center from Biotechnology Information (NCBI) using the Nucleotide collection (nr/nt) database and the discontiguous megablast algorithm (intended for cross-species comparisons).

The source and size of the cloned cDNA and the percent identity of the sequence to the ortholog of other species are summarized in Table 1. Of note, three different cDNA clones containing the 1084 bp hamster CCR4 ORF were isolated from cDNA that had been reverse transcribed at $55^{\circ} \mathrm{C}$ from mRNA from lymph node tissue of a hookworm infected hamster. Like the other cloned cDNAs, each clone was sequenced twice in each direction. Three DNA polymorphisms were detected in positions 165, 363 and 695. Position 165 and 695 are predicted to make changes in the amino acid sequence. The real-time RT PCR primers and probe for CCR4 were designed to avoid the polymorphic positions. The primers and probes used for all of the real time PCR assays are shown in Table 2.

For all the duplex RT-PCR assays the PCR product size was small (less than $200 \mathrm{bp}$ ), to limit the impact of infrequent RNA damage [27]. Because the amplification of the target gene and the reference gene ( $\gamma$-actin) were made in the same reaction tube, the concentrations of primers and probes of both genes were optimized to avoid preferential amplification of the more abundant transcript [28] (see Table 3). For an optimal duplex reaction the amplification efficiencies of the target and reference genes should be approximately equal $[29,30]$. Therefore, validation assays were performed by amplification of the target and reference genes using serial dilutions of RNA. In each of the real-time RT PCR assays, the efficiencies were estimated for both the target and reference mRNAs by determining the slope (log input concentration versus the difference in $\mathrm{Ct}$ (target minus reference) [31]) of the lines using the formula $E=10^{[-1 / \text { slope] }}[32,33]$. Real-time amplification efficiencies of both target and reference genes of $E=2$ are ideal [32]. To illustrate this, the amplification plots, standard curves and validation experiment data for CCR4 duplex assay, which are representative of all the genes studied, are shown in Figure 1. For the other assays the quality of the standard curves and amplification efficiencies can be judged from their slopes and correlation coefficients. In each case the absolute value of the slope of the line of each validation experiment was 0.1 or less (Table $4)$, indicating that the target and reference mRNAs were amplified with equal efficiencies. 
Table 1: Summary of Hamster cDNA sequences

\begin{tabular}{|c|c|c|c|c|c|c|c|}
\hline \multirow[t]{2}{*}{ Hamster Gene } & \multirow[t]{2}{*}{ Source of CDNA } & \multirow{2}{*}{$\begin{array}{c}\text { Cloned CDNA } \\
\text { fragment } \\
\text { size }\end{array}$} & \multicolumn{5}{|c|}{ Percent nucleotide identity of hamster CDNA compared to ortholog 1} \\
\hline & & & $\begin{array}{c}\text { Rattus } \\
\text { norvegicus }\end{array}$ & $\begin{array}{l}\text { Sigmodon } \\
\text { hispidus }\end{array}$ & $\begin{array}{l}\text { Peromyscus } \\
\text { maniculatus }\end{array}$ & Mus musculus & Homo sapiens \\
\hline IL-13 & $\begin{array}{l}\text { Lymph node from } \\
\text { hookworm infected hamster }\end{array}$ & $177 \mathrm{bp}$ & $81 \%$ & $85 \%$ & $83 \%$ & $80 \%$ & $76 \% *$ \\
\hline IL-21 & $\begin{array}{l}\text { Spleen from hookworm } \\
\text { infected hamster }\end{array}$ & $262 \mathrm{bp}$ & $90 \%$ & $\mathrm{~N} / \mathrm{A}^{2}$ & $95 \%$ & $92 \%$ & $84 \%$ \\
\hline CCL17 & $\begin{array}{l}\text { Hamster } \\
\text { cDNA library }\end{array}$ & $344 \mathrm{bp}$ & $89 \%$ & N/A & N/A & $86 \%$ & $77 \%$ \\
\hline CCL22 & $\begin{array}{c}\text { Hamster } \\
\text { CDNA library } \\
\text { Lymph node from }\end{array}$ & $310 \mathrm{bp}$ & $88 \%$ & $\mathrm{~N} / \mathrm{A}$ & $\mathrm{N} / \mathrm{A}$ & $89 \%$ & $82 \%$ \\
\hline CCR4 & $\begin{array}{l}\text { hookworm infected hamster } \\
\text { Lymph node from }\end{array}$ & $1084 \mathrm{bp}$ & $89 \%$ & $\mathrm{~N} / \mathrm{A}$ & $\mathrm{N} / \mathrm{A}$ & $90 \%$ & $83 \%$ \\
\hline FOXP3 & hookworm infected hamster & $581 \mathrm{bp}$ & $93 \%$ & $\mathrm{~N} / \mathrm{A}$ & $92 \%$ & $90 \%$ & $85 \%$ \\
\hline
\end{tabular}

The equal efficiencies of amplification of the target and reference mRNA allowed for the comparative Ct (2$\Delta \Delta \mathrm{Ct}$ ) method to be used to determine the relative level of gene expression $[34,35]$. This mathematical model calculates changes in gene expression as a relative fold difference between an experimental and a calibrator sample and includes a correction for non-ideal amplification efficiencies [34]. Hamster BHK cells, which generally express cytokines and chemokines at a low level, were used as the external calibrator to enable the calculation of basal levels of gene expression in the uninfected hamster. In this way, we avoided having to assign the levels of mRNA expression in uninfected hamsters to the arbitrary value of 1 , which enabled the variation in the uninfected group to be utilized in the statistical analysis. Because we used a relative method to calculate the gene expression, the numeric value of the fold change calculation depends on the $\mathrm{Ct}$ values of the normalizer and the calibrator used. With this approach, regardless of the calibrator used, the values of differences between the experimental groups are maintained. The low expression of the target genes in BHK cells allowed for the calculation of levels of expression such that the relative level of expression in the experi- mental tissue was always a positive value. Since the goal of these studies was to make comparison between the uninfected and infected tissue, determination of the absolute level of expression was unnecessary. The CT value for the target genes in BHK cells ranged from 32 to 40. For those genes that were expressed at a very low level $(\mathrm{Ct}=40)$ in BHK cells, such as Foxp3, there is a high level of calculated expression in both the uninfected and infected tissue. Conversely, for the genes expressed more highly in BHK cells, such as TGF- $\beta$ with a $\mathrm{Ct}=32$, the calculated level of expression in the hamster tissues is low. However, as noted above, this method is designed for the comparison of the two samples, in this case infected an uninfected tissue, and not for the absolute quantification of mRNA levels.

We used a well-established model of localized cutaneous leishmaniasis caused by L. panamensis $[1,3,4]$ to test the application of the standardized and validated duplex assays. In this model, at one-week post infection there is early evidence of a clinical lesion (inflammation and swelling) and parasites are easily identified in the tissue. Thereafter the lesion increases in size until 2-3 weeks post-infection when it is nodular with crusting and cen- 
Table 2: Hamster primers and probes used for duplex real-time RT PCR

\begin{tabular}{|c|c|c|c|}
\hline \multirow{2}{*}{$\begin{array}{l}\text { Hamster target gene } \\
\gamma \text {-actin }\end{array}$} & \multicolumn{2}{|c|}{$\begin{array}{l}\text { Primers and } \\
\text { probes sequences }\end{array}$} & \multirow{2}{*}{$\begin{array}{l}\text { Amplicon length (bp) } \\
70 \mathrm{bp}\end{array}$} \\
\hline & yactin-For & 5'-ACA GAG AGA AGA TGA CGC AGA TAA TG-3' & \\
\hline & pactin-Rev & 5'-GCC TGA ATG GCC ACG TAC A-3' & \\
\hline & pactin-Probe & 5'-VIC - TTG AAA CCT TCA ACA CCC CAG CC-(TAMRA)-3' & \\
\hline \multirow[t]{3}{*}{ IL-10 } & IL-10-F & 5'-GGT TGC CAA ACC TTA TCA GAA ATG-3' & $194 \mathrm{bp}$ \\
\hline & IL-10-R & 5'-TTC ACC TGT TCC ACA GCC TTG-3' & \\
\hline & IL-10-P & 5'-(6FAM) TGC AGC GCT GTC ATC GAT TTC TCC C-(TAMRA)-3' & \\
\hline \multirow[t]{3}{*}{ IL-4 } & $\mathrm{IL}-4-\mathrm{F}$ & 5'-ACA GAA AAA GGG ACA CCA TGC A-3' & $95 \mathrm{bp}$ \\
\hline & IL-4-R & 5'-GAA GCC CTG CAG ATG AGG TCT-3' & \\
\hline & IL-4-P & 5'-(6FAM) AGA CGC CCT TTC AGC AAG GAA GAA CTC C-(TAMRA)-3' & \\
\hline \multirow[t]{3}{*}{ IFN- $\gamma$} & IFN- $-\mathrm{F}$ & 5'-TGT TGC TCT GCC TCA CTC AGG-3' & $130 \mathrm{bp}$ \\
\hline & IFN- - -R & 5'-AAG ACG AGG TCC CCT CCA TTC-3' & \\
\hline & IFN- $-\mathrm{P}$ & 5'-(6FAM) TGG CTG CTA CTG CCA GGG CAC ACT C-(TAMRA)-3' & \\
\hline \multirow[t]{3}{*}{ IL-13 } & IL-13-F & 5'-AAA TGG CGG GTT CTG TGC-3' & $81 \mathrm{bp}$ \\
\hline & IL-13-R & 5'-AAT ATC CTC TGG GTC TTG TAG ATG G-3' & \\
\hline & IL-13-P & 5'-(6FAM)-TGG ATT CCC TGA CCA ACA TCT CTA GTT GC (TAMRA)-3' & \\
\hline \multirow[t]{3}{*}{ IL-21 } & IL-21-F & 5'-GGA CAG TGG CCC ATA AAA CAA G-3' & $80 \mathrm{bp}$ \\
\hline & IL-21-R & 5'-TTC AAC ACT GTC TAT AAG ATG ACG AAG TC-3' & \\
\hline & IL-21-P & 5'-(6FAM)-CAA GGG CCA GAT CGC CTC CTG ATT-(TAMRA)-3' & \\
\hline \multirow[t]{3}{*}{ TGF- $\beta 1$} & TGF $\beta 1-F$ & 5'-GGC TAC CAC GCC AAC TTC TG-3' & $81 \mathrm{bp}$ \\
\hline & TGF $\beta 1-R$ & 5'-GAG GGC AAG GAC CTT ACT GTA CTG-3' & \\
\hline & TGF $\beta 1-P$ & 5'-(6FAM)-CCC TGT CCC TAC ATT TGG AGC CTG GA-(TAMRA)-3' & \\
\hline \multirow[t]{3}{*}{ CCL17 } & CCL17-F & 5'-GTG CTG CCT GGA GAT CTT CA-3' & 89 bp \\
\hline & CCL17-R & 5'-TGG CAT CCC TGG GAC ACT-3'5'-TGG CAT CCC TGG GAC ACT-3' & \\
\hline & CCL17-P & 5'-(6FAM)-CCA TTC CCA TCA GGA AGC TGG TGA TG-(TAMRA)-3' & \\
\hline \multirow[t]{3}{*}{$\mathrm{CCL} 22$} & CCL22-F & 5'-TGG TGC CAA CGT GGA AGA C-3' & $82 \mathrm{bp}$ \\
\hline & CCL22-R & 5'-GAA GAA CTC CTT CAC TAC GCG C-3' & \\
\hline & CCL22-P & 5'-(6FAM)-CTG CTG CCA GGA CTA CAT CCG TCA GC-(TAMRA)-3' & \\
\hline \multirow[t]{3}{*}{ CCR4 } & CCR4-F & 5'-GCT TGG TCA CGT GGT CAG TG-3' & $80 \mathrm{bp}$ \\
\hline & CCR4-R & 5'-GTG GTT GCG CTC CGT GTA G-3' & \\
\hline & CCR4-P & 5'-(6FAM)-TCC CTC CCA GGC CTC TTG TTC AGC-(TAMRA)-3' & \\
\hline \multirow[t]{3}{*}{ FOXP3 } & FOXP3-F & 5'-GGT CTT CGA GGA GCC AGA AGA-3' & $72 \mathrm{pb}$ \\
\hline & FOXP3-R & 5'- GCC TTG CCC TTC TCA TCC A-3' & \\
\hline & FOXP3-P & 5'-(6FAM)-TाT CTC AAG CAC TGC CAA GCA GAT CAC C-(TAMRA)-3' & \\
\hline
\end{tabular}


Table 2: Hamster primers and probes used for duplex real-time RT PCR (Continued)

\begin{tabular}{|c|c|c|c|}
\hline \multirow[t]{3}{*}{ TNF-a } & TNF-a-F & 5'-TGA GCC ATC GTG CCA ATG-3' & \multirow[t]{3}{*}{$79 \mathrm{bp}$} \\
\hline & TNF-a-R & 5'-AGC CCG TCT GCT GGT ATC AC-3' & \\
\hline & TNF-a-P & 5'-(6FAM)-CGG CAT GTC TCT CAA AGA CAA CCA G-(TAMRA)-3' & \\
\hline \multirow[t]{3}{*}{ IL-12p40 } & IL-12p40-F & 5'-AAT GCG AGG CAG CAA ATT ACT C-3' & \multirow[t]{3}{*}{$88 \mathrm{bp}$} \\
\hline & IL-12p40-R & 5'-CTG CTC TTG ACG TTG AAC TTC AAG-3' & \\
\hline & IL-12p40-P & 5'-(6FAM)-CCT GCT GGT GGC TGA CTG CAA TCA-(TAMRA)-3' & \\
\hline
\end{tabular}

tral necrosis (see Figure 2). After 3-4 weeks postinfection it transitions to a stable chronic lesion containing fewer parasites (data not shown). We investigated the immune response early in the course of infection because the innate and early adaptive immune responses are known to shape the clinical outcome and immunity in other models of Leishmania infection [36,37].

The role of type 1 (IFN- $\gamma$ and IL-12p40) and type 2 (IL4, IL-10, IL-13, and IL-21) cytokines in the immunopathogenesis of leishmaniasis is well known [38]. Our studies to dissect the immunopathogenic mechanisms in this model of LCL are ongoing, but several aspects of this preliminary work deserve comment. After relative quantification and normalization, we found that there were tissue-specific differences in the basal expression of several genes (see Figures 3 and 4). There was relatively greater basal expression in the LN compared to the skin for most transcripts ( $\mathrm{p} \leq 0.05$ for IL-4, CCR4, IL-21, TNF$\alpha$, TGF- $\beta$, IFN- $\gamma$, IL-12p40, IL-10, and Foxp3). Conversely, the assays identified that basal expression of
CCL22 and CCL17 mRNAs was significantly greater in the normal skin compared to the $\mathrm{LN}(p \leq 0.05)$, consistent with their prominent expression in Langerhans cells (LCs) and immature dendritic cells (DCs) [39]. At an early stage (1 week post-infection) there was concomitant upregulation of the type 1 (IFN- $\gamma$ and IL-12p40) and type 2 (IL-4, IL-10, IL-13, and IL-21) cytokines at the site of cutaneous infection (Figure 2, $p<0.05$ for all). This mixed cytokine response is reminiscent of what is seen in chronic nonhealing, but nonprogressive, L. mexicana infection in some strains of mice [40]. We also found that the levels of CCL22 and CCL17 mRNAs, which are strongly up-regulated upon DC maturation [39,41], were up-regulated at the cutaneous site of infection of hamsters infected with L. panamensis (Figure 3A and 3B; $p<$ $0.05)$, consistent with the notion DCs are activated by Leishmania [42]. To our knowledge, this is the first demonstration of the induction of CCL17 and CCL22 expression in response to Leishmania infection. These chemokines have been implicated in the recruitment of

Table 3: GeneBank accession number, primer and probe concentrations for hamster Duplex real-time RT PCR assays

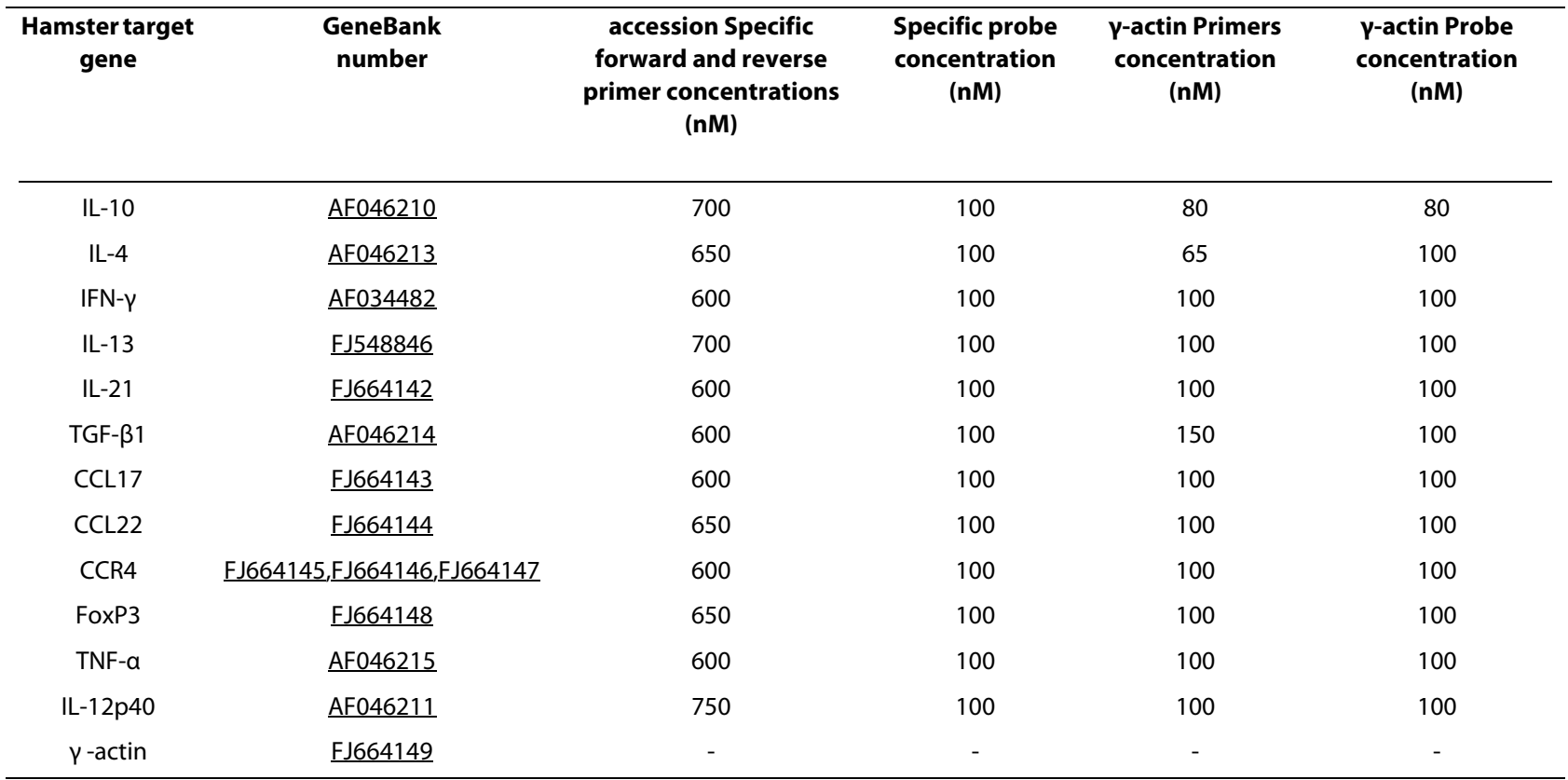


Table 4: Real-time RT PCR Standard curves and validation experiments

\begin{tabular}{|c|c|c|c|c|c|c|c|}
\hline \multirow[t]{2}{*}{$\begin{array}{l}\text { Hamster Duplex } \\
\text { real-time RT PCR }\end{array}$} & \multicolumn{2}{|c|}{$\begin{array}{c}\text { Slopes of the standard } \\
\text { curves }\end{array}$} & \multicolumn{2}{|c|}{ Correlation coefficient $\left(r^{2}\right)$} & \multicolumn{2}{|c|}{ Efficiencies } & \multirow{2}{*}{$\begin{array}{c}\text { Validation } \\
\text { experiment } \\
\text { (Absolute value) }\end{array}$} \\
\hline & Target gene & $\gamma$-actin & Target gene & $\boldsymbol{\gamma}$-actin & Target gene & $\gamma$-actin & \\
\hline IL-10 & -3.4094 & -3.4745 & 0.95 & 0.99 & 1.96 & 1.94 & 0.065 \\
\hline IL-4 & -3.0506 & -31576 & 0.98 & 0.98 & 2.12 & 2.07 & 0.107 \\
\hline $\mathrm{IFN}-\gamma$ & -3.2861 & -3.3459 & 0.93 & 0.93 & 2.01 & 1.99 & 0.059 \\
\hline IL-13 & -3.6531 & -3.6448 & 0.97 & 0.99 & 1.87 & 1.88 & 0.008 \\
\hline IL-21 & -3.2268 & -3.1831 & 0.98 & 0.98 & 2.04 & 2.06 & 0.043 \\
\hline TGF- $\beta 1$ & -3.4493 & -3.3399 & 0.98 & 0.98 & 1.94 & 1.99 & 0.109 \\
\hline CCL17 & -3.1135 & -3.1023 & 0.99 & 0.98 & 2.09 & 2.01 & 0.081 \\
\hline CCL22 & -3.2190 & -3.2269 & 0.99 & 0.98 & 2.04 & 2.04 & 0.008 \\
\hline CCR4 & -3.2155 & -3.2528 & 0.99 & 0.98 & 2.04 & 2.02 & 0.037 \\
\hline FoxP3 & -3.2598 & -3.1920 & 0.98 & 0.99 & 2.02 & 2.05 & 0.077 \\
\hline TNF- $a$ & -3.3286 & -3.4026 & 0.99 & 0.99 & 1.99 & 1.96 & 0.074 \\
\hline IL-12p40 & -3.4180 & -3.4917 & 0.94 & 0.99 & 1.96 & 1.93 & 0.073 \\
\hline
\end{tabular}

Standard curve slops, correlation coefficient ( $\mathrm{r} 2$ ), efficiencies and validation experiment results for hamster Duplex real-time RT PCR assays.

The efficiency estimation was calculated by $\mathrm{E}=10^{[-1 / \mathrm{slope}]}$.

activated Th2 cells and regulatory $\mathrm{T}$ cells, by signaling through the CC chemokine receptor 4 (CCR4) [43,44]. Consistent with this finding, at the site of cutaneous $L$. panamensis infection, we also found increased expression of Foxp3 (Figure 3L; $\mathrm{p}<0.05$ ), a transcription factor that is critical for the development and function of mouse CD4 ${ }^{+} \mathrm{CD} 25^{+}$regulatory T cells (Tregs) [45].

The sensitive real time RT PCR assays identified fewer infection-induced changes in gene expression in the LN compared to the skin at this early stage of infection. The response in the $\mathrm{LN}$ of infected hamsters was polarized toward a type 2 response with up-regulation of the type 2 cytokines (IL-4 ( $\mathrm{p}<0.05$, Figure 4B-D) and IL-13 (in 3 out of 6 animals; non-significant)), down-regulation of IL-12 (Figure 4J; $\mathrm{p}<0.05$ ), and upregulation of the type 2 chemokine CCL17 and its receptor CCR4 ( $<<0.05$, Figure 4B-D). Further studies will be needed to determine if the more restricted cytokine expression in the LN compared to the skin is simply because there is shorter period of exposure to parasites in the LN, or because there are organ specific mechanisms that lead to distinct cytokine responses.

\section{Conclusions}

The results presented here provide evidence that duplex real-time RT PCR is a powerful approach for the quantification of transcription immune response genes in the hamster model. Application of the assays developed here to a model of cutaneous leishmaniasis suggests that a bal- anced type 1 and type 2 cytokine response contributes to the chronic, nonprogressive nature of this disease. These new molecular tools will further facilitate investigation into the mechanisms of disease in the hamster, not only for models of leishmaniasis, but also for other viral, bacterial, fungal, and parasitic infections.

\section{Methods}

\section{Experimental animals}

Outbred Syrian golden hamsters (Mesocricetus auratus) were infected with hookworm as described previously [17]. Spleens and mesenteric lymph nodes (LNs) were harvested for isolation of mRNA and cloning of selected cDNAs. The model of localized cutaneous leishmaniasis was established by infecting 6-8 week old female hamsters $(\mathrm{n}=6)$ with $3 \times 10^{6}$ luciferase-transfected [46]L. panamensis promastigotes (MHOM/CO/94/1989) in the dermis of the snout. Lesion size was determined by measuring the diameter in two perpendicular directions and calculating the area of the lesion in $\mathrm{mm}^{2}$. The intralesional parasite burden was determined by in vivo imaging as follows: Hamsters were anesthetized with anesthetic cocktail (ketamine, acepromazine, and xylazine) and 20 $\mu \mathrm{L}$ of luciferin (Gold Biotechnology, St. Louis, MO) at 1.5 $\mathrm{mg} / \mathrm{mL}$ concentration were injected intradermally in the snout using a $31 \mathrm{G}$ needle. Ten minutes later the animals were placed in prone position inside the chamber of an IVIS50 imaging system (Caliper, Life Sciences, Hopkinton, MA) and the luminometric images captured using 

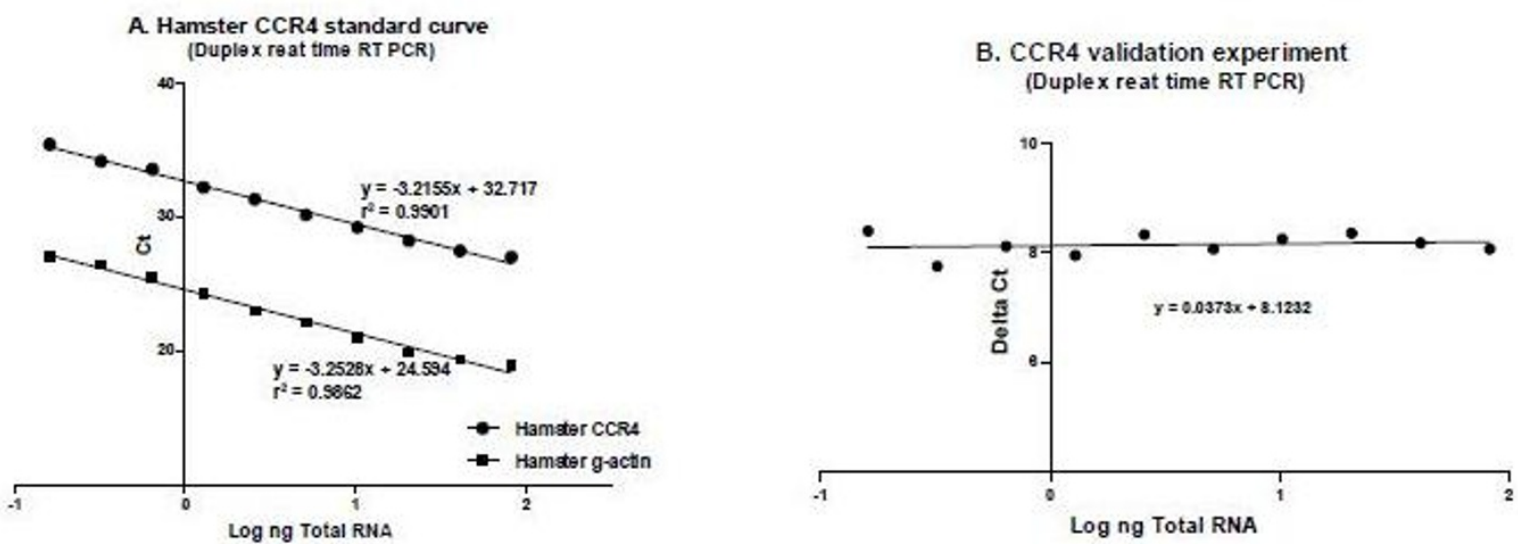

\section{CCR4 and $\gamma$-actin amplification plots (Duplex real time RT PCR)}
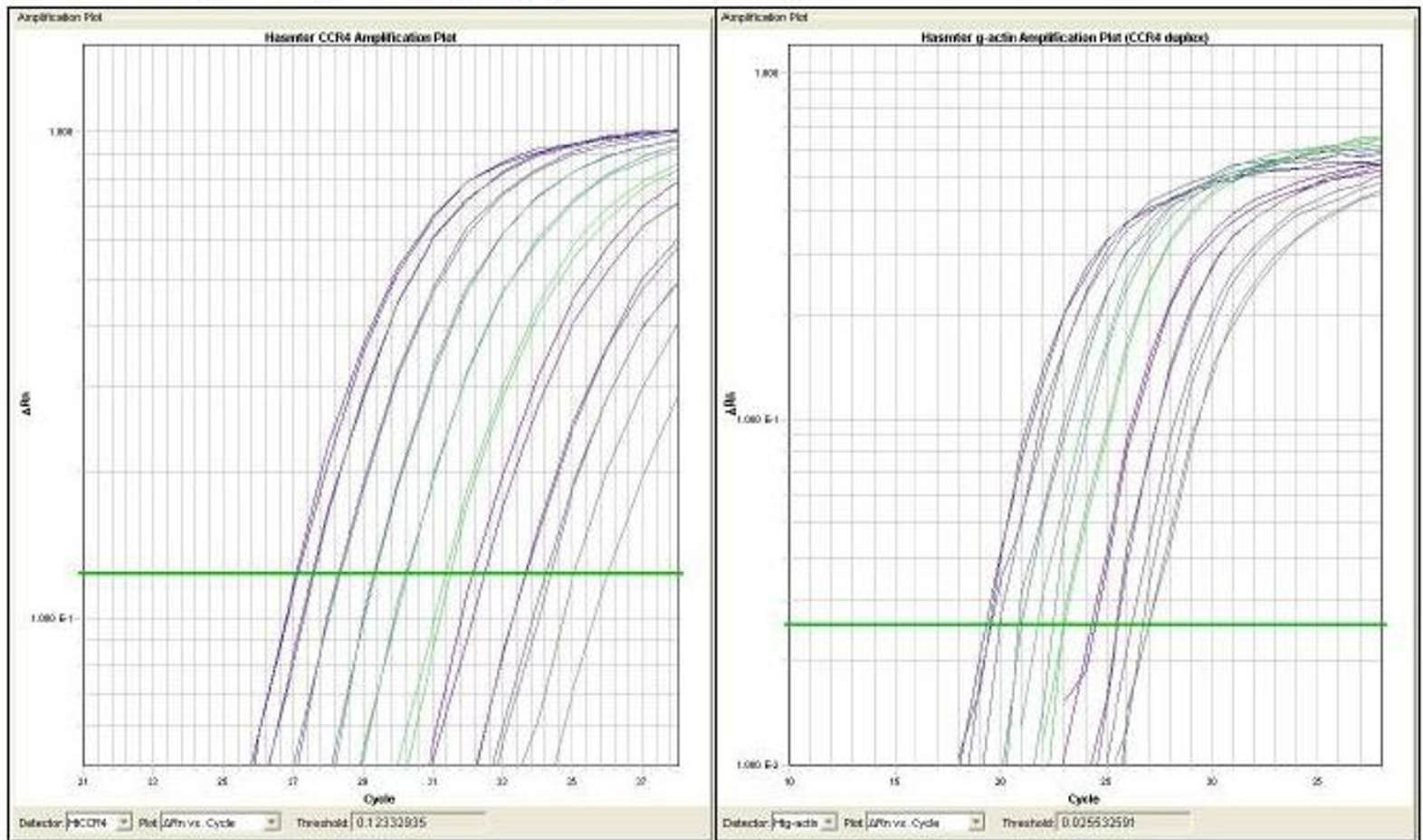

Figure 1 Real-time RT PCR standardization and validation. Standard curves (A), validation experiment (B) and amplification plots (C) for the hamster CCR4 duplex real-time Reverse Transcription (RT) PCR using TaqMan One-Step RT-PCR Master Mix, FAM-labeled probe for the target gene (hamster CCR4) and VIC-labeled probe for the endogenous control (hamster $\gamma$-actin).

medium binning and one minute exposure. The total parasite burden in the lesions was calculated by transforming photons/sec to parasite numbers using a standard curve of lesion-derived L. panamensis amastigotes obtained concurrently with the hamster evaluations. Animals used in this study were handled according to local and federal regulations, and research protocols were approved by our Institutional Animal Care and Use Committee.

\section{Cloning of hamster CDNAs}

Hamster IL-13, IL-21, CCR4 and Foxp3 were cloned from $1 \mu \mathrm{g}$ of total RNA isolated from lymph node or spleen tissue of a hookworm infected hamster [47]. The total RNA was reverse transcribed at 50 or $55^{\circ} \mathrm{C}$ using SuperScript III First-Strand Synthesis SuperMix (Invitrogen) and amplification was performed initially at a low annealing temperature $\left(45^{\circ} \mathrm{C}\right)$, with extension at $72^{\circ} \mathrm{C}$ for $1.5 \mathrm{~min}$ 

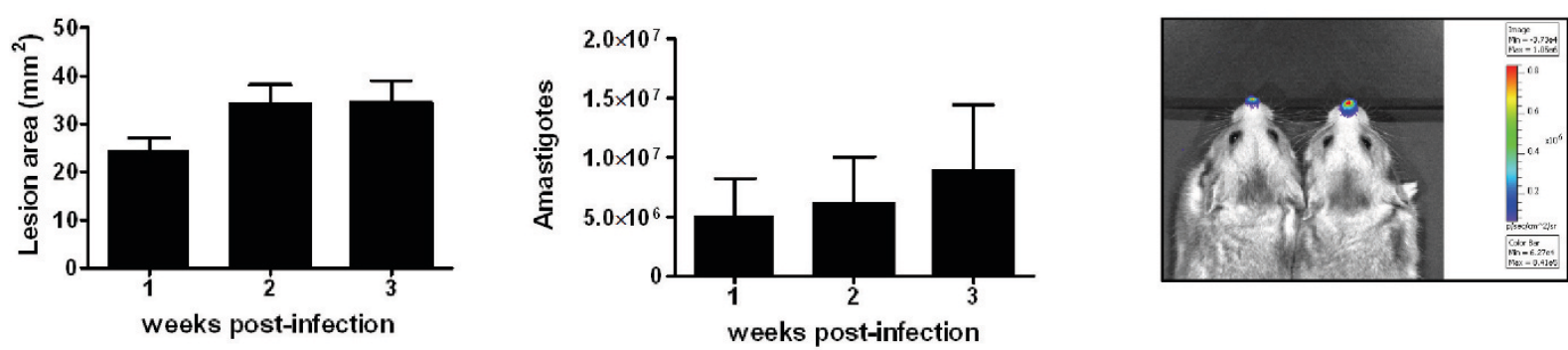

Figure 2 Course of disease and parasite burden in L. panamensis infected hamsters. 6- 8 week old female hamsters $(n=6)$ with $3 \times 10^{6}$ luciferase (luc)-transfected L. panamensis promastigotes in the dermis of the snout. Lesion size was measured weekly and is shown as the lesion area $\left(\mathrm{mm}{ }^{2}\right)$ in panel A. The intralesional parasite burden was determined by in vivo imaging and is shown as the total intralesional amastigotes in panel B. Images of the luc-L. panamensis burden in two representative hamsters are shown in panel $\mathrm{C}$.

and denaturation at $94^{\circ} \mathrm{C}$ for $1 \mathrm{~min}$. Reactions that produced amplification products were repeated at incrementally $\left(2\right.$ or $\left.3^{\circ} \mathrm{C}\right)$ higher annealing temperatures (up to $58^{\circ} \mathrm{C}$ ) until a single amplicon was achieved or all amplification products were lost. The hamster CCL17 and CCL22 cDNAs were cloned from 5 ng of plasmid DNA from a hamster cDNA library. Amplification was performed at $58^{\circ} \mathrm{C}$ annealing temperature, with extension at $72^{\circ} \mathrm{C}$ for $1.5 \mathrm{~min}$ and denaturation at $94^{\circ} \mathrm{C}$ for $1 \mathrm{~min}$. The oligonucleotide primers used in the RT-PCR amplification for cloning of cDNAs were designed from regions of homology found among the corresponding published human, mouse, rat, and deer mouse cDNA sequences. In most instances, the use of multiple primer combinations was required to successfully amplify a specific product of the appropriate size. Degenerate primers were used when there was incomplete homology among the published sequences and when nondegenerate primers failed to yield an amplification product. The sequences of the primers used to successfully amplify those genes are as follows (5' to 3 '):

IL-13: forward, gcagcatggtatggagcgtg; reverse, ccacttcrattttggtatc;

IL-21: forward, tastcatcttcttggggac; reverse ctttacatcttstggagctg;

CCL17: forward, aatcttcacctgcgttcctg; reverse, ctgcagtctcccaatgctc;

CCL22: forward, ggatgtaagtgcagcatggc; reverse, catcaggccttcttcaccag;

CCR4: forward, gatgaaccccacggatgtag; reverse, ttacaaagcgtcacggaggt;

Foxp3: forward, caaatggagtctgcaagtgg; reverse, gttgtggcggatggcatt.

The amplified cDNAs were cloned if they had a size similar to that predicted from the published homologous sequences and if it was the predominant amplification product of the reaction. In the case of hamster IL-13, two amplification products were cloned; the predominant amplification product was IL-13 genomic sequence including a intron-exon junction while the non-predominant amplification product corresponded to a small fragment of IL-13 mRNA. The amplification products were cloned into the $\mathrm{pCR}^{\circ} 2.1$-topo plasmid using the TOPO TA cloning kit from Invitrogen according to the manufacturer's instructions. Each cDNA insert was sequenced twice in each direction with vector-specific primers at The Nucleic Acids Core Facility of The University of Texas Health Science Center at San Antonio.

\section{Real-time Primers and probes for mRNA quantification}

Primers (forward and reverse) and TaqMan Fluorescentlabeled probes for real-time RT PCR assays were designed using Primer Express Software (Applied Biosystems, Foster City, CA) to specifically amplify hamster IL4, IFN- $\gamma$, TNF- $\alpha$, IL-10, IL- 12p40, TGF- $\beta$, IL-13, IL-21, CCL22, CCL17, CCR4, FOXP3 and $\gamma$-actin (GeneBank accession numbers in Table 3 . The validated sequences of the primers and probes are listed in Table 2.

\section{RNA isolation and real-time RT Polymerase Chain Reaction} mRNA expression in 7-day infected and uninfected age/ sex-matched control hamster tissues was determined by Duplex real-time RT PCR. After euthanasia of hamsters the snout skin and cervical lymph nodes were collected in RNA preservation buffer and frozen at $-80^{\circ} \mathrm{C}$ (RNAlater; Ambion) until the RNA was isolated. Total RNA was extracted from $20 \mathrm{mg}$ of tissue using the RNeasy kit (QIAGEN). All RNA samples were DNase treated with TURBO DNA-free $e^{\mathrm{ma}} \mathrm{kit}$ (Ambion) and quantified using a Thermo Scientific NanoDrop ${ }^{\mathrm{m}}$ Spectrophotometer and kept at $-80^{\circ} \mathrm{C}$ until ready to use. For Duplex real-time Reverse Transcription (RT) PCR of each target gene, $1 \mu \mathrm{l}$ of RNA (10 $\mathrm{ng} / \mu \mathrm{l}$ per sample or corresponding dilution for standard curves) were combined with a specific set of oligonucleotide primers, FAM-target gene-TAMRA labeled probe, $\gamma$-actin primers, VIC- $\gamma$-actin-TAMRA 


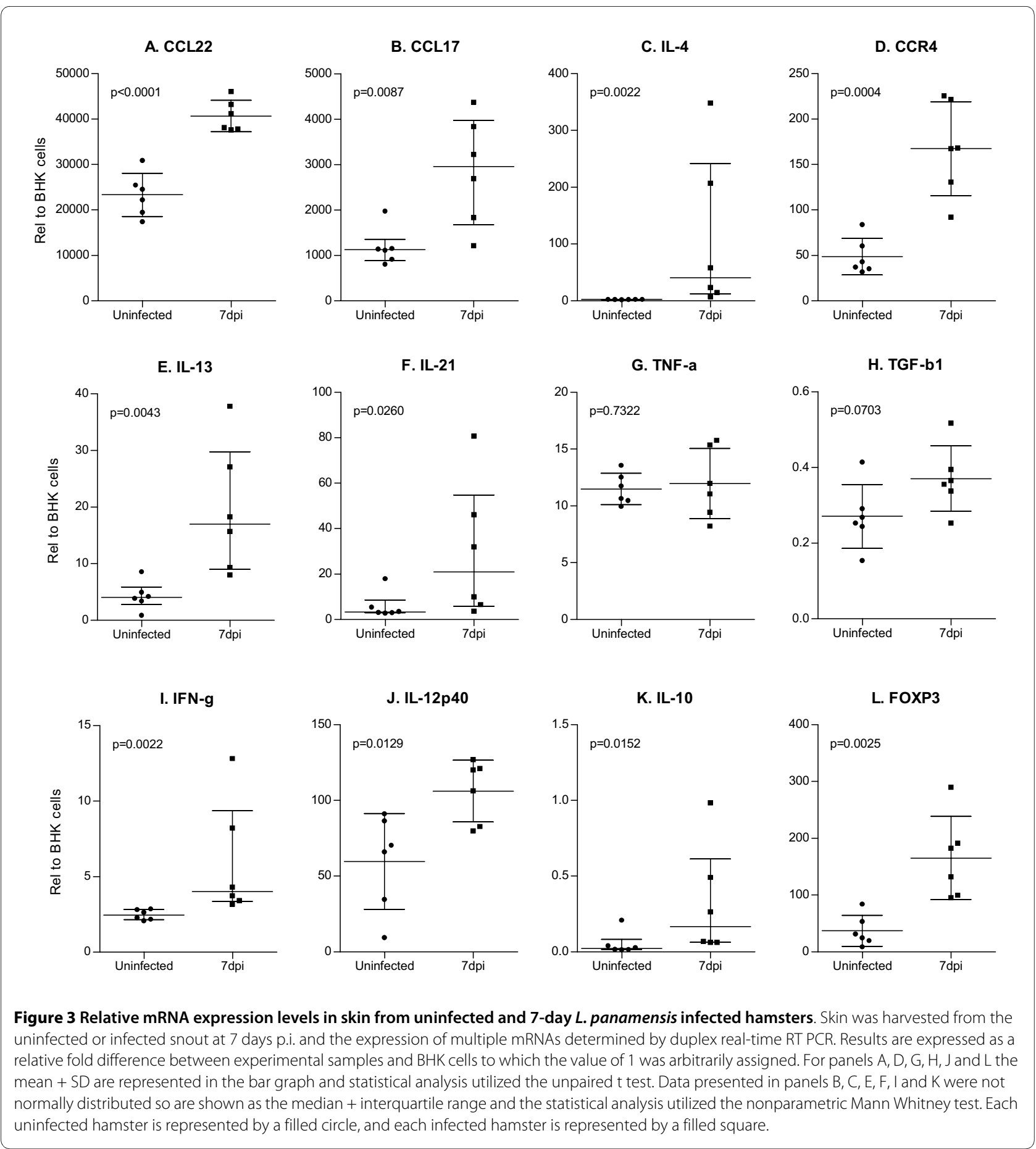

labeled probe, and 40X MultiScribe and RNase inhibitor mix in $25 \mu \mathrm{l}$ of a total reaction volume using TaqMan One-Step RT-PCR Master Mix (Applied Biosystems). The PCR samples were subjected to an initial incubation for 30 minutes at $48^{\circ} \mathrm{C}$ (RT reaction) followed by 10 minutes at $95^{\circ} \mathrm{C}$ (AmpliTaq Gold pre-activation) and then, 40 cycles of $95^{\circ} \mathrm{C}$ for $15 \mathrm{sec}$ and $60^{\circ} \mathrm{C}$ for 1 minute in an 7900 HT Fast Real-Time PCR System (Applied Biosystems).
Hamster $\gamma$-actin was used as an endogenous control to normalize differences in the amount of input RNA in each Duplex assay. Prior to acceptance of data for relative quantification, at least five standard curve dilutions for each Duplex assay were required. To validate equivalent efficiency of each target gene and $\gamma$-actin in the same duplex real time RT reaction, standard curves were generated from comparator RNA samples (expressing the 


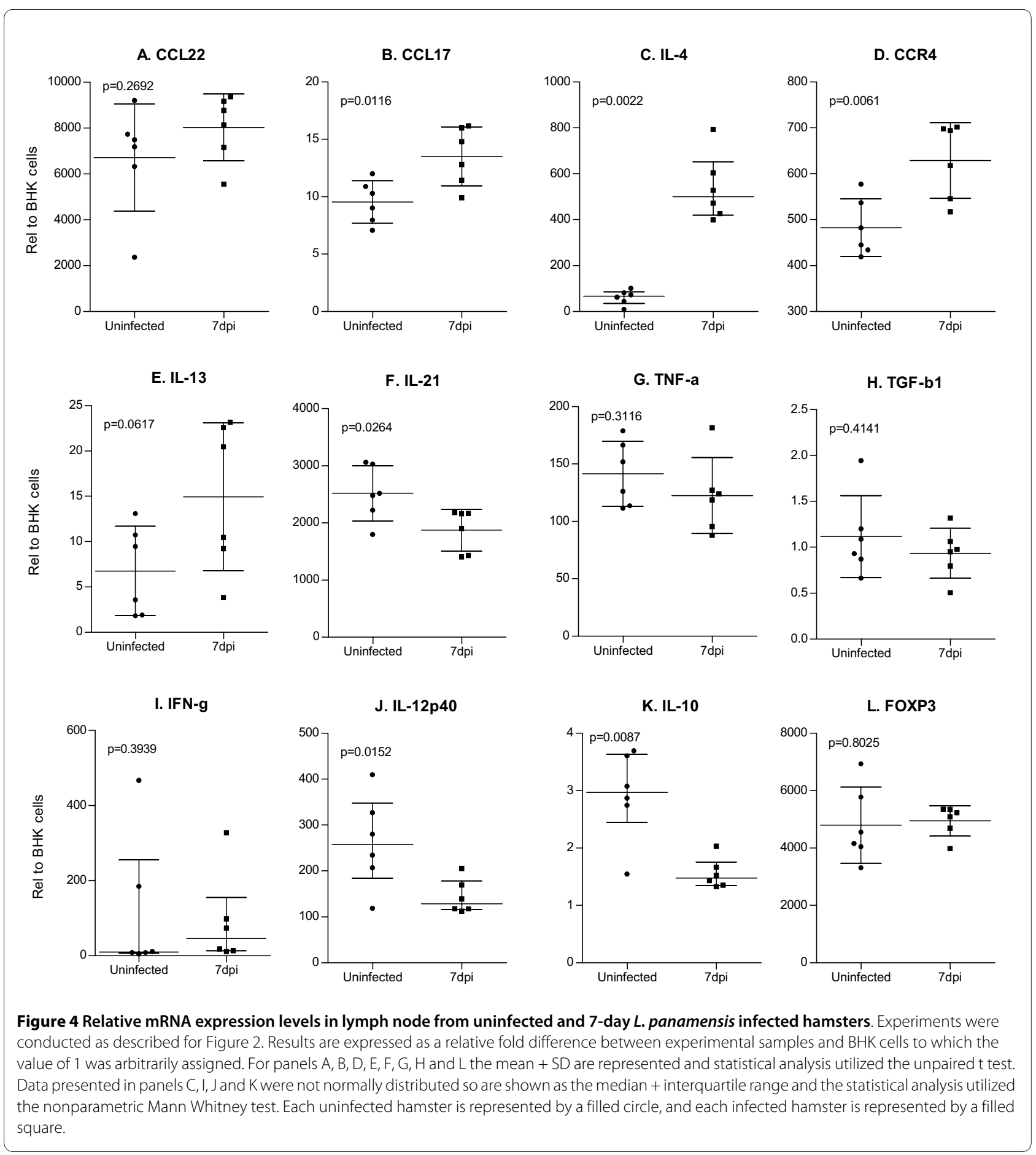

gene of interest) made from decreasing (2-fold dilution) amounts of RNA. Once the Real Time RT PCR assays were validated, $10 \mathrm{ng}$ of RNA from each experimental animal were used to quantify mRNA expression. The comparative $\mathrm{Ct}(2-\Delta \Delta \mathrm{Ct})$ method was used to study the experimental samples and RNA isolated from the BHK (hamster fibroblast) cell line was used as a calibrator.

\section{Statistical analysis}

Differences in mRNA expression between non-infected animals and the animals 7-days post infection were analyzed by two tail Man-Whitney test or two tail unpaired ttest using GraphPad Prism version 5.01 for Windows, GraphPad Software, San Diego California USA, http:// www.graphpad.com 


\section{Authors' contributions}

CME conducted cloning, real-time RT PCR design, standardization, validation and application experiments; WZ cloned CDNAs; OS designed real-time RT PCR primers and probes and provided expert discussion related to real-time RT PCR; MC and LMH conducted the hookworm infections and harvest of tissue. BLT conducted the hamster Leishmania infections. PCM provided direction and oversight to the entire project. All authors contributed to the experimental design and manuscript preparation, and all authors have read and approved the manuscript.

\section{Acknowledgements}

This work was supported by the funding from the National Institutes of Health (Al61624) and the U.S. Department of Veterans Affairs to PCM, and NIH grant Al058980 to MC. Special thanks to Lourdes Arteaga and Alheli Rodriguez for technical assistance.

\section{Author Details}

'Research Service, Department of Veterans Affairs Medical Center, South Texas Veterans Health Care System, 7400 Merton Minter, San Antonio, Texas, USA, 2Department of Medicine, The University of Texas Health Science Center, 7703 Floyd Curl Drive, San Antonio, Texas, USA, ${ }^{3}$ Department of Pediatrics, Yale School of Medicine, P.O. Box 208064. New Haven, Connecticut, USA and ${ }^{4}$ Department of Microbiology and Immunology, The University of Texas Health Science Center, 7703 Floyd Curl Drive, San Antonio, Texas, USA

Received: 25 November 2009 Accepted: 22 June 2010

Published: 22 June 2010

\section{References}

1. Hommel M, Jaffe CL, Travi B, Milon G: Experimental models for leishmaniasis and for testing anti-leishmanial vaccines. Ann Trop Med Parasitol 1995, 89(Suppl 1):55-73.

2. Requena JM, Soto M, Doria MD, Alonso C: Immune and clinical parameters associated with Leishmania infantum infection in the golden hamster model. Vet Immunol Immunopathol 2000, 76:269-81.

3. Travi BL, Osorio Y, Saravia NG: The inflammatory response promotes cutaneous metastasis in hamsters infected with Leishmania (Viannia) panamensis. J Parasitol 1996, 82:454-7.

4. Martinez JE, Travi BL, Valencia AZ, Saravia NG: Metastatic capability of Leishmania (Viannia) panamensis and Leishmania (Viannia) guyanensis in golden hamsters. J Parasito/ 1991, 77:762-8.

5. Melby PC, Chandrasekar B, Zhao W, Coe JE: The hamster as a model of human visceral leishmaniasis: progressive disease and impaired generation of nitric oxide in the face of a prominent Th1-like response. J Immunol 2001, 166:1912-20.

6. Melby PC, Tryon W, Chandrasekar B, Freeman GL: Cloning of Syrian hamster (Mesocricetus auratus) cytokine cDNAs and analysis of cytokine mRNA expression in experimental visceral leishmaniasis. Infect Immun 1998, 66:2135-42.

7. Bilate AM, Salemi VM, Ramires FJ, de Brito T, Silva AM, Umezawa ES, Mady C, Kalil J, Cunha-Neto E: The Syrian hamster as a model for the dilated cardiomyopathy of Chagas' disease: a quantitative echocardiographical and histopathological analysis. Microbes Infect 2003, 5:1116-24.

8. Rigothier MC, Khun H, Tavares P, Cardona A, Huerre M, Guillen N: Fate of Entamoeba histolytica during establishment of amoebic liver abscess analyzed by quantitative radioimaging and histology. Infect Immun 2002, 70:3208-15

9. Kajdacsy-Balla A, Howeedy A, Bagasra O: Syphilis in the Syrian hamster. A model of human venereal and congenital syphilis. Am J Pathol 1987, 126:599-601.

10. Haake DA: Hamster model of leptospirosis. Curr Protoc Microbiol 2006, Chapter 12(Unit 12E 2):

11. Campen MJ, Milazzo ML, Fulhorst CF, CJ Obot Akata, Koster F: Characterization of shock in a hamster model of hantavirus infection. Virology 2006, 356:45-9.

12. Paessler S, Aguilar P, Anishchenko M, Wang HQ, Aronson J, Campbell G, Cararra AS, Weaver SC: The hamster as an animal model for eastern equine encephalitis--and its use in studies of virus entrance into the brain. J Infect Dis 2004, 189:2072-6.
13. Tesh RB, Guzman H, AP da Rosa, Vasconcelos PF, Dias LB, Bunnell JE, Zhang $H$, Xiao SY: Experimental yellow fever virus infection in the Golden Hamster (Mesocricetus auratus). I. Virologic, biochemical, and immunologic studies. J Infect Dis 2001, 183:1431-6.

14. Xiao SY, Zhang H, Guzman H, Tesh RB: Experimental yellow fever virus infection in the Golden hamster (Mesocricetus auratus). II. Pathology. J Infect Dis 2001, 183:1437-44.

15. Xiao SY, Guzman H, Zhang H, AP Travassos da Rosa, Tesh RB: West Nile virus infection in the golden hamster (Mesocricetus auratus): a mode for West Nile encephalitis. Emerg Infect Dis 2001, 7:714-21.

16. Wong KT, Grosjean I, Brisson C, Blanquier B, Fevre-Montange M, Bernard A, Loth P, Georges-Courbot MC, Chevallier M, Akaoka H, et al:: A golden hamster model for human acute Nipah virus infection. Am J Pathol 2003, 163:2127-37.

17. Held MR, Bungiro RD, Harrison LM, Hamza I, Cappello M: Dietary iron content mediates hookworm pathogenesis in vivo. Infect Immun 2006, 74:289-95.

18. Mendez S, Valenzuela JG, Wu W, Hotez PJ: Host cytokine production, lymphoproliferation, and antibody responses during the course of Ancylostoma ceylanicum infection in the Golden Syrian hamster. Infect Immun 2005, 73:3402-7.

19. Travi BL, Osorio Y, Melby PC, Chandrasekar B, Arteaga L, Saravia NG: Gender is a major determinant of the clinical evolution and immune response in hamsters infected with Leishmania spp. Infect Immun 2002, 70:2288-96.

20. Jittimanee J, Sermswan RW, Puapairoj A, Maleewong W, Wongratanacheewin S: Cytokine expression in hamsters experimentally infected with Opisthorchis viverrini. Parasite Immunol 2007, 29:159-67.

21. Rama Iniguez S, Dea-Ayuela MA, Sanchez-Brunete JA, Torrado JJ, Alunda $J M$, Bolas-Fernandez F: Real-time reverse transcription-PCR quantification of cytokine mRNA expression in golden Syrian hamster infected with Leishmania infantum and treated with a new amphotericin B formulation. Antimicrob Agents Chemother 2006, 50:1195-201

22. Vernel-Pauillac F, Merien F: Proinflammatory and immunomodulatory cytokine mRNA time course profiles in hamsters infected with a virulent variant of Leptospira interrogans. Infect Immun 2006, 74:4172-9.

23. Sher A, Coffman RL: Regulation of immunity to parasites by $T$ cells and $T$ cell-derived cytokines. Annu Rev Immunol 1992, 10:385-409.

24. Shannon MF, Coles LS, Attema J, Diamond P: The role of architectural transcription factors in cytokine gene transcription. J Leukoc Biol 2001, 69:21-32.

25. Sparkman L, Boggaram V: Nitric oxide increases IL-8 gene transcription and mRNA stability to enhance IL-8 gene expression in lung epithelial cells. Am J Physiol Lung Cell Mol Physiol 2004, 287:L764-73.

26. Altschul SF, Gish W, Miller W, Myers EW, Lipman DJ: Basic local alignment search tool. J Mol Biol 1990, 215:403-10.

27. Ginzinger DG: Gene quantification using real-time quantitative PCR: an emerging technology hits the mainstream. Exp Hematol 2002, 30:503-12.

28. Liu W, Saint DA: A new quantitative method of real time reverse transcription polymerase chain reaction assay based on simulation of polymerase chain reaction kinetics. Anal Biochem 2002, 302:52-9.

29. Bustin SA: Absolute quantification of mRNA using real-time reverse transcription polymerase chain reaction assays. J Mol Endocrinol 2000 25:169-93.

30. Medhurst AD, Harrison DC, Read SJ, Campbell CA, Robbins MJ, Pangalos MN: The use of TaqMan RT-PCR assays for semiquantitative analysis of gene expression in CNS tissues and disease models. J Neurosci Methods 2000, 98:9-20

31. Wong ML, Medrano JF: Real-time PCR for mRNA quantitation. Biotechniques 2005, 39:75-85

32. Pfaffl MW: A new mathematical model for relative quantification in realtime RT-PCR. Nucleic. Acids Res 2001, 29:e45.

33. Pfaffl MW, Horgan GW, Dempfle L: Relative expression software tool (REST) for group-wise comparison and statistical analysis of relative expression results in real-time PCR. Nucleic Acids Res 2002, 30:e36.

34. Livak KJ, Schmittgen TD: Analysis of relative gene expression data using real-time quantitative PCR and the 2(-Delta Delta C(T)) Method. Methods 2001, 25:402-8. 
35. Schmittgen TD, Livak KJ: Analyzing real-time PCR data by the comparative C(T) method. Nat Protoc 2008, 3:1101-8.

36. Laskay T, Diefenbach A, Rollinghoff M, Solbach W: Early parasite containment is decisive for resistance to Leishmania major infection [published erratum appears in Eur J Immunol 1995 Sep;25(9):2726]. Eur J Immunol 1995, 25:2220-7.

37. Scharton-Kersten T, Scott $P$ : The role of the innate immune response in Th1 cell development following Leishmania major infection. J Leukoc Biol 1995, 57:515-22

38. Sacks D, Noben-Trauth N: The immunology of susceptibility and resistance to Leishmania major in mice. Nat Rev Immuno/ 2002, 2:845-58.

39. Alferink J, Lieberam I, Reindl W, Behrens A, Weiss S, Huser N, Gerauer K, Ross R, Reske-Kunz AB, Ahmad-Nejad P, et al: Compartmentalized production of CCL17 in vivo: strong inducibility in peripheral dendritic cells contrasts selective absence from the spleen. J Exp Med 2003, 197:585-99.

40. Rosas LE, Keiser T, Barbi J, Satoskar AA, Septer A, Kaczmarek J, LezamaDavila CM, Satoskar AR: Genetic background influences immune responses and disease outcome of cutaneous L. mexicana infection in mice. Int Immunol 2005, 17:1347-57.

41. Lieberam I, Forster I: The murine beta-chemokine TARC is expressed by subsets of dendritic cells and attracts primed CD4+ T cells. Eur J Immunol 1999, 29:2684-94.

42. Ng LG, Hsu A, Mandell MA, Roediger B, Hoeller C, Mrass P, Iparraguirre A, Cavanagh LL, Triccas JA, Beverley SM, et al:: Migratory dermal dendritic cells act as rapid sensors of protozoan parasites. PLoS Pathog 2008, 4:e1000222

43. Cavassani KA, Campanelli AP, Moreira AP, Vancim JO, Vitali LH, Mamede RC, Martinez R, Silva JS: Systemic and local characterization of regulatory $T$ cells in a chronic fungal infection in humans. $J$ Immunol 2006, 177:5811-8.

44. Imai T, Nagira M, Takagi S, Kakizaki M, Nishimura M, Wang J, Gray PW, Matsushima K, Yoshie O: Selective recruitment of CCR4-bearing Th2 cells toward antigen-presenting cells by the CC chemokines thymus and activation-regulated chemokine and macrophage-derived chemokine. Int Immunol 1999, 11:81-8.

45. Lopes JE, Soper DM, Ziegler SF: Foxp3 is required throughout the life of a regulatory T cell. SciSTKE 2007, 2007:pe36.

46. Roy G, Dumas C, Sereno D, Wu Y, Singh AK, Tremblay MJ, Ouellette M, Olivier M, Papadopoulou B: Episomal and stable expression of the luciferase reporter gene for quantifying Leishmania spp. infections in macrophages and in animal models. Mol Biochem Parasitol 2000 110:195-206.

47. Dondji B, Bungiro RD, Harrison LM, Vermeire JJ, Bifulco C, D McMahonPratt, Cappello M: Role for nitric oxide in hookworm-associated immune suppression. Infect Immun 2008, 76:2560-7.

Submit your next manuscript to BioMed Central and take full advantage of:

- Convenient online submission

- Thorough peer review

- No space constraints or color figure charges

- Immediate publication on acceptance

- Inclusion in PubMed, CAS, Scopus and Google Scholar

- Research which is freely available for redistribution

Submit your manuscript at www.biomedcentral.com/submit
C Biomed Central 